\title{
Intensive lifestyle modification program on weight loss and metabolic syndrome risk reduction among obese women in rural areas of Thailand
}

\author{
Charunee Thiabpho and Supranee Changbumrung \\ Department of Nutrition and Food Science, Faculty of Tropical Medicine, \\ Mahidol University, Bangkok, Thailand \\ Ngamphol Soonthornworasiri \\ Department of Tropical Hygiene, Faculty of Tropical Medicine, \\ Mahidol University, Bangkok, Thailand \\ Bencha Yoddumnern-Attig \\ Institute of Population and Social Research, Mahidol University, \\ Nakhon Pathom, Thailand \\ Patcharaporn Thaboot \\ Pralub Health Promotion Hospital, Khon Kaen, Thailand \\ Pattharawan Nissayan \\ Banpue Health Promotion Hospital, Khon Kaen, Thailand, and \\ Karunee Kwanbunjan \\ Department of Nutrition and Food Science, Faculty of Tropical Medicine, \\ Mahidol University, Bangkok, Thailand
}

\begin{abstract}
Purpose - The purpose of this paper is to examine the effect of the intensive lifestyle modification program on weight and metabolic syndrome risk reduction in rural obese women who have no underlying non-communicable diseases in Thailand.

Design/methodology/approach - A randomized controlled trial was conducted. In total, 60 healthy obese women aged 30-50 years were recruited and randomly assigned to either the intervention $(n=30)$ or control $(n=30)$ group after health screening. Tailored nutritional counseling, health education and exercise training were included in the lifestyle modification program. Behavioral modification techniques were also incorporated. The intervention was conducted weekly for the first eight weeks, then biweekly until week 16.
\end{abstract}

(C) Charunee Thiabpho, Supranee Changbumrung, Ngamphol Soonthornworasiri, Bencha Yoddumnern-Attig, Patcharaporn Thaboot, Pattharawan Nissayan and Karunee Kwanbunjan. Published in the Journal of Health Research. Published by Emerald Publishing Limited. This article is published under the Creative Commons Attribution (CC BY 4.0) licence. Anyone may reproduce, distribute, translate and create derivative works of this article (for both commercial \& non-commercial purposes), subject to full attribution to the original publication and authors. The full terms of this licence may be seen at: http://creativecommons.org/ licences/by/4.0/legalcode

Conflict of interests: there is no conflict of interests to be declared. This study was supported by a grant from the Faculty of Tropical Medicine, Mahidol University, Thailand. The authors thank all participants for joining the study, the staff from Phalub, Banpue, Bankaeng district health promotion hospitals, and the nursing instructors from the College of Asian Scholars, Khon Kaen Province.
Intensive lifestyle modification

program

Received 8 August 2017 Accepted 26 December 2017 
JHR

32,3

204

Findings - The student's $t$-test was used to compare mean difference between groups. The total weight loss in the intervention group $(n=29)$ was significantly higher, $7.6 \pm 2.9 \mathrm{~kg}$, compared with the control group $(n=30)$ who lost $0.7 \pm 1.4 \mathrm{~kg}(p<0.001)$. The intervention group lost weight 10.2 percent from baseline which was significantly higher than that in the control group $(p<0.001)$. Systolic and diastolic blood pressures, fasting blood sugar, and waist circumference were significantly improved. Triglyceride levels slightly improved while high density lipoprotein cholesterol was slightly lowered. The intervention group showed a statistical reduction in abnormal components of metabolic syndrome compared with the control group, with the relative risk $=0.24,95 \%$ confidence interval $=0.072-0.791$, and $p=0.018$.

Originality/value - Compatibility of the program activities conducted by a health professional who had achieved healthy weight loss and accepted as a role model was a key to achieving effective weight loss and metabolic syndrome risk reduction in obese women in rural areas. The program should be integrated into the conventional practice of health care centers.

Keywords Obesity, Metabolic syndrome, Weight loss, Intensive lifestyle modification programme

Paper type Research paper

\section{Introduction}

Obesity is a global public health problem[1]. In Thailand, the prevalence of obesity has been increasing at an alarming rate in all life stages[2]. The prevalence of obesity has been reported[3] to be high among women aged 30-44 years (44.2 percent) and 45-59 years (50.6 percent) in Thailand. Also, obesity is positively associated with lower education levels[4], particularly in rural areas[5].

Excess visceral fat often found in obesity is associated with metabolic syndrome, type 2 diabetes mellitus, hypertension, coronary artery disease, and stroke[6, 7]. The larger the amount of visceral fat accumulation, the greater the risk for developing metabolic syndrome and other diseases[8, 9]. Modest weight loss can improve metabolic parameters and prevent non-communicable diseases[10, 11]. In rural municipal areas, the prevalence of obesity in women was high[5] although they could receive health information about obesity and management from health care centers and other information sources in Thailand. Weight loss is difficult because it is associated with habits, attitudes, and cultural norms[12]. In general, behavior modification programs combined with health education based on a health belief model[13] can enhance practical lifestyle modification skills compatible with individual contexts for managing weight[14] because individuals might make decision to change positively once individuals perceive their risk and severity of the risk threatening their life. Also, they are likely to act when they perceive that their changes gain more benefits and are able to do it[13]. Health belief model focuses on individual's health concerns, and it is suitable for adults because they can decide to improve their health based on their health perception[13]. Thus, any behavioral modification intended to result in weight loss should be compatible with the individual's practical aspects of their lifestyle and contexts over the long-term.

The purpose of the study was to examine, on the community level, the effects of the intensive lifestyle modification (ILM) program (including proposes health education based on a health belief model components and linkages[15], counseling, and exercise training) on weight and metabolic syndrome risk reduction in obese women in rural areas in Thailand.

\section{Materials}

\section{Study design and research settings}

A randomized controlled trial was conducted for 16 weeks between March and July 2014 among women with a low education in rural area, Khon Kaen Province, Thailand. Three study sites were chosen: primary health care centers in municipal areas with similar population sizes, basic health services, and convenient food access. 


\section{Participants}

Potential participants were initially screened from each health center database of the Java Health Center Information System during 2013 with approval of the Ministry of Public Health. In two-week recruitment before implementing the program, those participants in all villages under the responsibility of each primary health care center obtained information about the program objectives and procedures benefits, risks and criteria of the recruiting participants via local village radio announcements, village health volunteers, and notice boards in the village. In total, 220 participants were assessed for eligibility ( 82 from primary health care center 1, 73 from center 2, and 65 from center 3$)$. Inclusion criteria were females, aged between 30 and 50 years, having normal menstrual periods, body mass index $(\mathrm{BMI}) \geqslant 27.5 \mathrm{~kg} / \mathrm{m}^{2}$, no chronic diseases, no history of drug use, no pregnancy, no breastfeeding, and no other weight loss program participation. A sample size was calculated using the test of difference in two independent means[16]. A minimum of 24 participants in each group was determined using triglyceride based on previous similar study[17]. We adjusted it to fit with our sample area by using mean and standard deviation of triglyceride for the intervention group as 155.0 and $9.50 \mathrm{mg} / \mathrm{dl}$ and the control group as 165 and $11.50 \mathrm{mg} / \mathrm{dl}$, respectively, power 90 percent, type I error $(\alpha) 0.05$, effect size 0.9 and ratio (r) 1.60 participants were randomly chosen at each group in 1:1 ratio: 30 were randomly assigned to the ILM program and 30 were randomly assigned to be the control group. In all, 30 participants at each group allowing for 20 percent of the drop-out rate (Figure 1).

\section{ILM program}

Following an initial survey, an ILM program was designed to fit with the individual's circumstances. This new program was developed based on the theory of the health belief model components with linkages[15], which suggests that an increase in health awareness fosters a positive health impact. The program was designed to focus on the individual's health concerns and self-efficacy and help them recognize their susceptibility to obesity, its co-morbidities, and its potential life-threatening severity. Expectantly, individuals would change their lifestyles when they perceive the benefits of positive lifestyle changes, particularly with regards to diet and physical activity. The model aims to increase health concerns and provide them with confidence to overcome any perceived barriers via counseling,

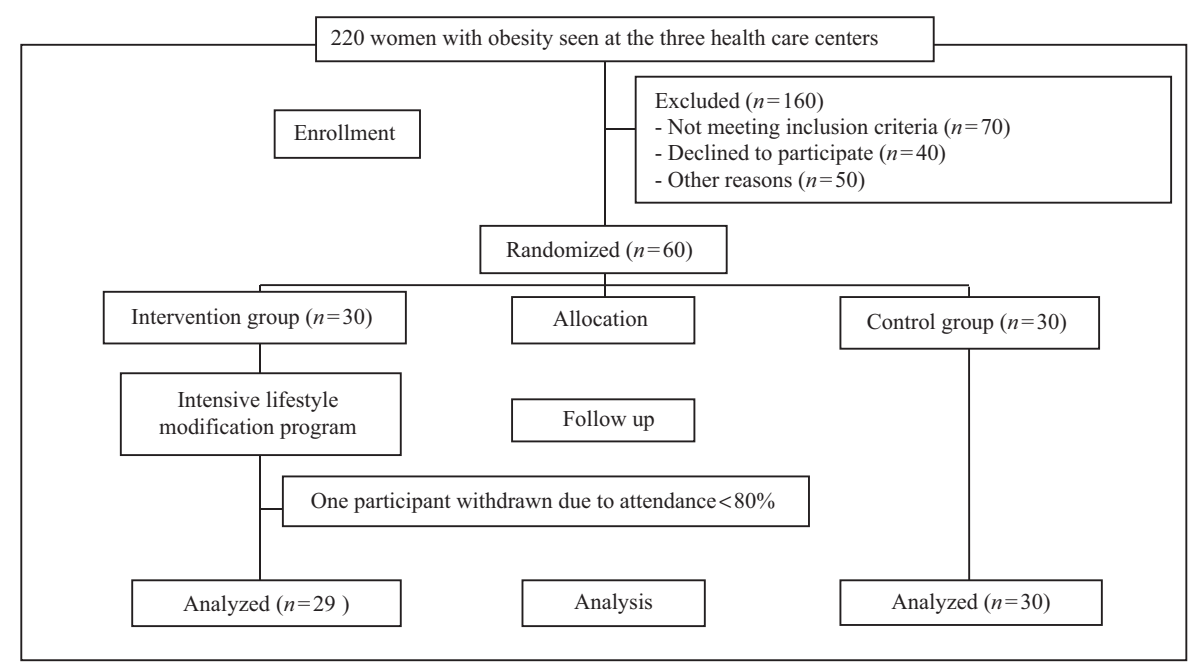

Intensive lifestyle modification program
Figure 1.

Flow chart of the study 
JHR

32,3

206

health education, and exercise training. Motivational interviewing was employed to inspire the participants to adhere to the recommended diet and exercise regime[18, 19]. Concept of the health education preparation and exercise regime in this study were partially modified from a diabetes prevention program, health education session preparation and brisk walking $\geqslant 150$ minutes per week[20]. Behavioral modification techniques were also employed accompanied by counseling, health education, and exercise training. These behavioral modification techniques included: first, mutual goal setting and commitment; 5 to 10 percent of weight loss; second, monitoring; weekly weight measurement, weight loss monitoring graph record and food and physical activity tracker record; third, peer support; sharing experiences of weight loss practices and of feelings among the program members; fourth, reinforcement; positive feedback and encouragement; and fifth role model; the healthy weight of the health professional.

The program was implemented for 16 weeks during the summer. The intervention consisted of 12 sessions, once a week for the first eight weeks and then every two weeks until the 16th week. Each session included 9 to 11 participants and lasted 90 to 120 minutes including 30-45 minutes of exercise. Importantly, each session was conducted in the community by a health professional who was a role model in healthy weight loss (69 to $59 \mathrm{~kg}$ in four months), and a trained preparation assistant. At the end of each session, participants received a small sample of healthy food that included fresh fruits and low fat milk. There were three main components of the intervention conducted including tailored nutrition counseling, health education and exercise training.

The first component was a tailored nutritional counseling[21] with motivational interviewing[18, 19] for establishing a client-centered counseling style. This component aimed at increase in understanding about individual energy requirement and expenditure. The motivational interviewing concept was employed to motivate the participants to maintain the required $1,200 \pm 200 \mathrm{kcal} /$ day balanced diet depending on their body demand and agreement, to increase physical activity and to maintain a minimum of 150 minutes/week of moderate exercise. The counseling focused on issues related to the individual's risk factors, the health screening and laboratory results, existing health problems due to obesity, positive health impacts from weight loss, negative energy balance methods, individual eating and the physical activity recommendations. This tailored nutrition counseling was provided for 20-30 minutes following an extra appointment during the first week of the implementation one time for each participant. They could ask for special appointment for an extra counseling session as needed. Then, 3-5 minutes of counseling was provided to assess the participants' practices during each session relating with weekly daily food and physical activity tracker records kept by participants.

The second component was health education based on the health belief model components and linkages aimed at increasing the severity, susceptibility and threats regarding obesity and health, understanding benefits and barriers relating to weight loss, increasing individual's ability regarding diet and exercise and stimulating cues to lose weight. The health education was also delivered by using flexible and diverse teaching methods for adults to maximize the learning process. The core health education included four parts: discussing obesity and its co-morbidities, linking obesity and its co-morbidities, metabolic syndrome definition, health impacts from lifestyle modification, energy balance concept and the food exchange list at weeks 1, 5, and 9; discussing energy intake assessment, demonstrating healthy cooking and calorie counting to support self-efficacy and sharing experiences of weight loss at weeks 2, 6, and 10; discussing the causes of obesity and its co-morbidities, the obstacles of lifestyle modification, importance of exercise and avoidable food and sharing weight loss practices and solutions at weeks 3, 7, and 11; and discussing eating out strategies, food labels and sources of sodium and sharing methods of stimulus control and self-motivation 
at weeks 4, 8, and 12. Repeated sessions helped clarify and fulfill group discussions regarding complex and ambiguous contents provided. In addition, an educational manual and pamphlets about metabolic syndrome, exercise, calories in food, food exchange list, and low calorie diet were given to all participants.

The third component included an exercise training session conducted with popular songs to increase individual's ability in performing exercise. At the end of each session, the participants performed 20 to 25 minutes per session of moderate intensity exercise, including 5 minutes of warm up steps, and 15 minutes of resistance band training involving 10 to 15 repetitive movements of each gross muscle followed by 5 minutes of cool down steps. All exercise trainings were led by the health professional to demonstrate the correct procedures, motivate the participants, and modulate the exercise level to increase the heart rate to a maximum of 50-69 percent [22] which was about $\leqslant 125$ beats/minutes relating to the maximum heart rates assessed in the intervention group 74 beats/minutes. The participants were supervised to plan and perform accumulative exercise at moderate intensity $(\geqslant 10$ minutes/session) for at least 150 minutes/week along with resistance exercise at least twice a week.

\section{Outcome measures}

Assessments including anthropometric indices, blood pressure, fasting blood sugar, triglyceride, high density lipoprotein cholesterol, food and physical activity records, and questionnaires were performed by trained nurses at baseline and the 16th week in each of the three communities.

\section{Anthropometric indices and metabolic syndrome components}

Height was measured without shoes. After a $12 \mathrm{~h}$ overnight fast, body weight was measured with a high precision digital scale (Zepper, TCS-150L, China). BMI was calculated from body weight $(\mathrm{kg})$ divided by the height squared $\left(\mathrm{m}^{2}\right)$. Body fat, visceral fat, and fat-free mass were measured by bioelectric impedance analysis (Omron Karada Scan Body Composition and Scale, HBF-361; Omron, Japan). Waist circumference (WC) was measured midway between the lowest rib and the iliac crest. Blood pressure was measured in a sitting position with an automatic digital sphygmomanometer (Omron Automatic Blood Pressure Monitor, SME-1) after resting for at least 15 minutes. The average of two readings with $<5 \mathrm{mmHg}$ differences taken at a 1-minute interval was used. Blood samples were obtained and transferred in an ice box to the clinical laboratory at the Health Promotion Hospital Center, Khon Kaen Province within $1 \mathrm{~h}$.

\section{Energy and nutrients}

Each participant kept food records for three days including two weekdays and one weekend day. They were trained in this process and given a food record manual. Energy and nutrients were calculated using the NutriSurvey program and the food composition database provided by the Nutrition Division, Ministry of Public Health, Thailand[23].

\section{Knowledge, attitude, and physical activity}

The questionnaires of knowledge of obesity and health and attitude toward lifestyle modification were developed by the authors. The validity of the questions was approved by a panel of experts in nursing science and nutrition. For the knowledge part, the difficulty and discrimination of each calculated item were 0.2 to 0.8 and $>0.2$. The reliabilities of 18 knowledge and 22 attitude items calculated using the Cronbach's $\alpha$ were 0.836 and 0.841 . In the knowledge part, the participants received 1 point for correct answers and 0 for either a wrong or "I don't know" answer, and the knowledge scores were $\geqslant 80$ percent, $70-79$ percent, 
JHR

32,3

60-69 percent, and $<60$ percent of the total scores[24]. A five-score scale in the attitude part varied from strong disagreement (1 score) to strong agreement $(5$ scores) for positive statements[25]. These scores were inverted for negative attitude statements. For physical activity, a habitual physical activity record log with a specific time of 1 week was kept by each participant. The average physical activity in metabolic equivalent of task (MET) was estimated following the Compendium of Physical Activities, an update of activity codes and MET intensities[26]. The individual's MET was calculated following the Guide to the Assessment of Physical Activity[22].

\section{Statistical analysis}

Statistical analysis of data was conducted using the Statistical Package for Social Sciences Version 16.0. Data were analyzed following statistical rules. Kolmogorov-Smirnov and Levene's test were performed for normal distribution and homogeneity evaluation of data before using comparison statistics. Paired $t$-tests and Student's $t$-tests were used to compare the difference within and between the groups for continuous variables, respectively. The $\chi^{2}$ test was used for comparisons of categorical variables. The relative risk of developing metabolic syndrome for the intervention group compared with the control group was also computed by using univariate logistic regressions. A $p$-value of $<0.05$ was considered significant.

\section{Ethical considerations}

The study was approved by the Ethics Committee of the Faculty of Tropical Medicine, Mahidol University, Bangkok, Thailand (MUTM 2014-009-01).

\section{Results}

A Kolmogorov-Smirnov showed the sample data were normally distributed $(p>0.05)$, and Levene's test was used to verify the equality of variance before determining Student's $t$-test.

\section{Characteristics of the participants}

In total, 59 women were retained (dropout rate 1.67 percent). The participants had an average age of about 42.68 years $(\mathrm{SD}=5.24, \mathrm{max} / \mathrm{min}$ of age $=30 / 50)$, average BMI $32.37 \mathrm{~kg} / \mathrm{m}^{2}(\mathrm{SD}=3.81)$, mostly farmers with literacy levels at an elementary level, and relatively low income. Their physical activity was at a light level, 1.6-2.9 METs[22]. All baseline characteristics of the intervention and control groups showed no significant differences (Table I).

\section{Changes in anthropometric indices and metabolic syndrome components}

The intervention group showed significant improvement in anthropometric indices while the control group displayed only slight improvement regarding body weight, BMI, and WC. The magnitudes of the changes in anthropometric indices in the intervention group were significantly greater than those in the control group. Mean weight loss was $7.6 \mathrm{~kg}$ (10.2 percent) in the intervention group and $0.7 \mathrm{~kg}$ ( 0.9 percent) in the control group. Most metabolic syndrome components, except triglyceride and high density lipoprotein cholesterol, showed significantly greater improvement in the intervention group than in the control group (Table II).

\section{Changes in energy and nutrients}

At baseline, there were no statistical differences in energy and nutrient intake between the groups (Table III). An average amount of energy (1,920 kcal/day) consumed by the participants was high in relation to their physical activity ("light level" in Table IV) and 


\begin{tabular}{|c|c|c|c|c|}
\hline Variables & $\begin{array}{c}\text { Intervention }(n=29) \\
\overline{\mathrm{x}} \pm \mathrm{SD}\end{array}$ & $\begin{array}{c}\text { Control }(n=30) \\
\overline{\mathrm{x}} \pm \mathrm{SD} \\
\end{array}$ & $p$-value ${ }^{\mathrm{a}}$ & $\begin{array}{l}\text { Intensive } \\
\text { lifestyle }\end{array}$ \\
\hline $\begin{array}{l}\text { Age (years) } \\
\text { Max./Min. of age (years) }\end{array}$ & $\begin{array}{c}43.8 \pm 4.8 \\
30 / 50\end{array}$ & $\begin{array}{c}43.0 \pm 0.7 \\
30 / 50\end{array}$ & 0.671 & $\begin{array}{l}\text { program } \\
\text { progrion }\end{array}$ \\
\hline \multicolumn{5}{|l|}{ Education (n \%) } \\
\hline Elementary school & $20(69.0 \%)$ & $19(63.4 \%)$ & \multirow[b]{2}{*}{0.200} & 209 \\
\hline $\begin{array}{l}\text { Middle school } \\
\geqslant \text { Secondary school }\end{array}$ & $\begin{array}{l}3(10.3 \%) \\
6(20.7 \%)\end{array}$ & $\begin{array}{l}3(10.0 \%) \\
8(26.6 \%)\end{array}$ & & \\
\hline \multicolumn{5}{|l|}{ Monthly income } \\
\hline$<\mathrm{US} \$ 300$ & $27(93.1 \%)$ & $26(86.6 \%)$ & \multirow{2}{*}{0.740} & \\
\hline$\geqslant \mathrm{US} \$ 300$ & $2(6.9 \%)$ & $4(13.3 \%)$ & & \\
\hline Body weight (kg) & $75.5 \pm 10.8$ & $77.5 \pm 9.4$ & 0.452 & \\
\hline BMI $\left(\mathrm{kg} / \mathrm{m}^{2}\right)$ & $31.9 \pm 3.7$ & $32.7 \pm 3.9$ & 0.398 & \\
\hline Waist-hip ratio & $0.9 \pm 0.1$ & $0.9 \pm 0.6$ & 0.427 & \\
\hline Body fat $(\%)$ & $38.5 \pm 3.0$ & $39.00 \pm 3.3$ & 0.555 & \\
\hline Visceral fat & $14.8 \pm 4.9$ & $15.8 \pm 5.6$ & 0.482 & \\
\hline Free-fat mass $(\%)$ & $22.6 \pm 1.5$ & $22.4 \pm 1.6$ & 0.664 & \\
\hline Waist circumference $(\mathrm{cm})$ & $100.6 \pm 8.2$ & $101.1 \pm 7.7$ & 0.805 & \\
\hline Fasting blood sugar (mg/dl) & $99.3 \pm 15.9$ & $98.2 \pm 11.0$ & 0.756 & \\
\hline Triglyceride (mg/dl) & $160.5 \pm 138.4$ & $170.0 \pm 92.1$ & 0.757 & \\
\hline High density lipoprotein cholesterol (mg/dl) & $51.6 \pm 13.5$ & $50.0 \pm 9.5$ & 0.595 & \\
\hline Systolic blood pressure $(\mathrm{mmHg})$ & $116.7 \pm 9.7$ & $116.8 \pm 12.9$ & 0.970 & \\
\hline Diastolic blood pressure (mmHg) & $74.3 \pm 8.5$ & $73.1 \pm 8.2$ & 0.580 & \\
\hline Knowledge (scores) & $10.1 \pm 3.7$ & $11.2 \pm 4.3$ & 0.296 & \\
\hline Attitude (scores) & $3.9 \pm 0.4$ & $3.8 \pm 0.3$ & 0.580 & \\
\hline Physical activity (METs) & $1.7 \pm 0.2$ & $1.7 \pm 0.2$ & 0.636 & Table 1. \\
\hline Energy intake (kcal/day) & $1,920.5 \pm 426.7$ & $1,861.1 \pm 429.5$ & 0.596 & $\begin{array}{l}\text { Baseline } \\
\text { istics of the }\end{array}$ \\
\hline \multicolumn{4}{|c|}{ Notes: METs, metabolic equivalent of tasks. ${ }^{\text {aThe }}$ were no significant differences between the groups } & participan \\
\hline
\end{tabular}

small body structure. At program completion, the energy intake had significantly decreased from its baseline in the intervention group, but this was not seen in the control group. The changes that occurred met the Thai Dietary Reference Intake, 2003[27] guidelines for essential nutrients. In the control group, there was significant change for protein and fat.

Changes in knowledge, attitude, and physical activity

The average knowledge about obesity and health, attitudes toward lifestyle modification, and physical activity of the participants at baseline showed no significant difference between the groups. Their average knowledge scores were low and their attitude tended toward strong agreement. Their physical activity was also at a light level. At the program completion, the mean scores of knowledge, attitude, and physical activity for the intervention group showed statistically greater improvement than the control group. Their average knowledge scores were 15.9 out of 18.0 indicating $>80$ percent of the total scores. Also, there was an improvement of 5.8 scores in the intervention group compared with only 1.8 scores in the control group with a $p$-value $<0.001$ (Table IV).

\section{Changes in percentage and relative risk of metabolic syndrome}

Metabolic syndrome criteria following the National Cholesterol Education-Adult Treatment Panel III (ATP III) of the Asian WC cutoff points were used to categorize the participants[28]. Table $\mathrm{V}$ shows that the number of participants with $\geqslant 3$ abnormal metabolic syndrome components in the intervention group was statistically lower than that in the control group at the program completion. Hence, the percentage of metabolic syndrome decreased in the 
JHR
32,3

Table II.

Changes in anthropometric indices and metabolic syndrome components

\begin{tabular}{|c|c|c|c|c|c|c|}
\hline$\underline{\text { Variables }}$ & Group & $\begin{array}{c}\text { At baseline } \\
\overline{\mathrm{x}} \pm \mathrm{SD}\end{array}$ & $\begin{array}{c}\text { At week } 16 \\
\quad \overline{\mathrm{x}} \pm \mathrm{SD}\end{array}$ & $\begin{array}{c}\text { Paired } t \text {-test } \\
p \text {-value }\end{array}$ & $\begin{array}{l}\text { Change } \\
\overline{\mathrm{x}} \pm \mathrm{SD}\end{array}$ & $\begin{array}{c}\text { Student's } t \text {-test } \\
p \text {-value }\end{array}$ \\
\hline \multicolumn{7}{|l|}{ Anthropometric indices } \\
\hline Body weight (kg) & $\begin{array}{l}\text { Int. } \\
\text { Con. }\end{array}$ & $\begin{array}{c}75.5 \pm 10.8 \\
77.5 \pm 9.5\end{array}$ & $\begin{array}{c}67.9 \pm 10.9 \\
76.8 \pm 9.8\end{array}$ & $\begin{array}{c}<0.001^{* * *} \\
0.005^{* *}\end{array}$ & $\begin{array}{l}-7.6 \pm 2.9 \\
-0.7 \pm 1.4\end{array}$ & $<0.001^{* * * *}$ \\
\hline BMI $\left(\mathrm{kg} / \mathrm{m}^{2}\right)$ & $\begin{array}{l}\text { Int. } \\
\text { Con. }\end{array}$ & $\begin{array}{l}31.9 \pm 3.7 \\
32.8 \pm 3.9\end{array}$ & $\begin{array}{l}28.7 \pm 3.9 \\
32.5 \pm 4.1\end{array}$ & $\begin{array}{c}<0.001^{* * * *} \\
0.005^{*}\end{array}$ & $\begin{array}{c}-3.2 \pm 1.2 \\
0.9 \pm 1.8\end{array}$ & $<0.001 * * *$ \\
\hline Waist-hip ratio & $\begin{array}{l}\text { Int. } \\
\text { Con. }\end{array}$ & $\begin{array}{l}0.90 \pm 0.1 \\
0.89 \pm 0.6\end{array}$ & $\begin{array}{l}0.86 \pm 0.1 \\
0.89 \pm 0.1\end{array}$ & $\begin{array}{c}<0.001 * * * \\
0.391\end{array}$ & $\begin{array}{c}-0.0 \pm 0.0 \\
0.0 \pm 0.0\end{array}$ & $<0.001^{* * *}$ \\
\hline Body fat (\%) & $\begin{array}{l}\text { Int. } \\
\text { Con. }\end{array}$ & $\begin{array}{l}38.5 \pm 3.0 \\
39.0 \pm 3.3\end{array}$ & $\begin{array}{l}34.8 \pm 4.1 \\
38.9 \pm 3.0\end{array}$ & $\begin{array}{c}<0.001^{* * * *} \\
0.366\end{array}$ & $\begin{array}{l}-3.7 \pm 2.1 \\
-0.1 \pm 2.0\end{array}$ & $<0.001^{* * * *}$ \\
\hline Visceral fat & $\begin{array}{l}\text { Int. } \\
\text { Con. }\end{array}$ & $\begin{array}{l}14.8 \pm 4.9 \\
15.8 \pm 5.6\end{array}$ & $\begin{array}{l}10.9 \pm 4.6 \\
15.7 \pm 5.6\end{array}$ & $\begin{array}{c}<0.001 * * * * \\
0.213\end{array}$ & $\begin{array}{l}-3.9 \pm 1.7 \\
-0.1 \pm 1.0\end{array}$ & $<0.001^{* * * *}$ \\
\hline Fat-free mass $(\%)$ & $\begin{array}{l}\text { Int. } \\
\text { Con. }\end{array}$ & $\begin{array}{l}22.6 \pm 1.5 \\
22.4 \pm 1.6\end{array}$ & $\begin{array}{l}24.1 \pm 1.9 \\
22.5 \pm 1.6\end{array}$ & $\begin{array}{l}<0.001^{* * * *} \\
0.121\end{array}$ & $\begin{array}{l}1.5 \pm 1.0 \\
0.1 \pm 0.6\end{array}$ & $<0.001^{* * * *}$ \\
\hline \multicolumn{7}{|c|}{ Metabolic syndrome components } \\
\hline WC (cm) & $\begin{array}{l}\text { Int. } \\
\text { Con. }\end{array}$ & $\begin{array}{l}100.6 \pm 8.2 \\
101.1 \pm 7.7\end{array}$ & $\begin{array}{l}89.5 \pm 9.1 \\
99.2 \pm 7.8\end{array}$ & $\begin{array}{c}<0.001^{* * * *} \\
0.001^{* *}\end{array}$ & $\begin{array}{c}-11.1 \pm 4.8 \\
-1.9 \pm 3.2\end{array}$ & $<0.001^{* * * *}$ \\
\hline FBS & $\begin{array}{l}\text { Int. } \\
\text { Con. }\end{array}$ & $\begin{array}{l}99.3 \pm 15.9 \\
98.2 \pm 11.0\end{array}$ & $\begin{array}{c}95.0 \pm 7.2 \\
102.9 \pm 19.2\end{array}$ & $\begin{array}{l}0.034^{*} \\
0.025\end{array}$ & $\begin{array}{c}-4.3 \pm 12.1 \\
4.7 \pm 12.6\end{array}$ & $0.004^{* *}$ \\
\hline Triglyceride (mg/dl) & $\begin{array}{l}\text { Int. } \\
\text { Con. }\end{array}$ & $\begin{array}{c}160.5 \pm 138.4 \\
170.0 \pm 92.1\end{array}$ & $\begin{array}{l}110.6 \pm 51.0 \\
158.0 \pm 94.1\end{array}$ & $\begin{array}{l}0.015^{*} \\
0.162\end{array}$ & $\begin{array}{c}-49.9 \pm 111.8 \\
-12.0 \pm 65.3\end{array}$ & 0.062 \\
\hline HDL-C (mg/dl) & $\begin{array}{l}\text { Int. } \\
\text { Con. }\end{array}$ & $\begin{array}{c}51.6 \pm 13.5 \\
50.0 \pm 9.5\end{array}$ & $\begin{array}{l}49.6 \pm 10.4 \\
49.6 \pm 10.5\end{array}$ & $\begin{array}{l}0.145 \\
0.375\end{array}$ & $\begin{array}{l}-2.0 \pm 10.0 \\
-0.4 \pm 6.6\end{array}$ & 0.235 \\
\hline Systolic BP (mmHg) & $\begin{array}{l}\text { Int. } \\
\text { Con. }\end{array}$ & $\begin{array}{c}116.7 \pm 9.7 \\
116.8 \pm 13.0\end{array}$ & $\begin{array}{c}109.3 \pm 8.9 \\
114.7 \pm 10.1\end{array}$ & $\begin{array}{c}<0.001^{* * * *} \\
0.254\end{array}$ & $\begin{array}{l}-7.4 \pm 6.8 \\
-2.1 \pm 9.6\end{array}$ & $0.009^{* *}$ \\
\hline Diastolic BP (mmHg) & $\begin{array}{l}\text { Int. } \\
\text { Con. }\end{array}$ & $\begin{array}{l}74.3 \pm 8.5 \\
73.1 \pm 8.2\end{array}$ & $\begin{array}{l}69.1 \pm 8.1 \\
71.9 \pm 8.8\end{array}$ & $\begin{array}{c}<0.001 * * * \\
0.394\end{array}$ & $\begin{array}{l}-5.2 \pm 5.8 \\
-1.2 \pm 7.2\end{array}$ & $0.011^{*}$ \\
\hline
\end{tabular}

Notes: Int., intervention group $(n=29)$; Con., control group $(n=30)$; BMI, body mass index; FBS, fasting blood sugar; HDL-C, high density lipoprotein cholesterol; BP, blood pressure. ${ }^{*} p<0.05 ;{ }^{* *} p<0.01$; $* * * p<0.001$

intervention group by 19.5 percent (37.9 to 17.3 percent) whereas it increased by 3.4 percent (43.3-46.7 percent) in the control group. Furthermore, the participants in the intervention group had a 76.0 percent reduced chance of developing metabolic syndrome (relative risk $=0.24,95 \%$ confidence interval $=0.072-0.791$ ).

\section{Discussion}

The substantial improvements in all the anthropometric indices and most of the metabolic syndrome components in the intervention group imply that the ILM program was effective. The effective weight loss in this study was 10.2 percent greater than in previous studies because those involved longer lifestyle modifications that required several specialists and thus, implying higher cost-effectiveness to achieve high weight loss.

Pettman et al.[29] investigated weekly health education $(2 \mathrm{~h})$ for 16 weeks and an exercise instruction session $(1 \mathrm{~h})$ conducted by a study coordinator and an exercise instructor, which led to a 2.4 percent weight loss, and Tsai and Felton[30] used 12 individual counseling sessions (20 to 30 minutes) with portion-controlled food conducted by a lay-trained counselor and managed to produce a 6.5 percent weight loss after six months. A six-month therapeutic lifestyle modification study conducted by a community health nurse included 60 sessions of health monitoring (5 minutes/session), health education (20 minutes), exercise performance (40 minutes), and counseling for a $<1,500 \mathrm{kcal} / \mathrm{day}$ 


\begin{tabular}{|c|c|c|c|c|c|c|c|}
\hline Variables & $\begin{array}{l}\text { Intervention } \mathrm{g} \\
\text { At baseline } \\
\qquad \overline{\mathrm{x}}_{ \pm \mathrm{SD}}\end{array}$ & $\begin{array}{c}\text { group }(n=29) \\
\text { At week } 16 \\
\overline{\mathrm{x}} \pm \mathrm{SD}\end{array}$ & $\begin{array}{c}\text { Paired } t \text {-test } \\
p \text {-value }\end{array}$ & $\begin{array}{l}\text { Control gro } \\
\text { At baseline } \\
\overline{\mathrm{x}} \pm \mathrm{SD}\end{array}$ & $\begin{array}{l}(n=30) \\
\text { At week } 16 \\
\overline{\mathrm{x}} \pm \mathrm{SD}\end{array}$ & $\begin{array}{c}\text { Paired } t \text {-test } \\
p \text {-value } \\
\end{array}$ & $\begin{array}{r}\text { lifestyle } \\
\text { modification } \\
\text { program }\end{array}$ \\
\hline Energy (kcal) & $1,920.5 \pm 426.7$ & $1,195.6 \pm 221.5$ & $<0.001^{* * *}$ & $1,861.1 \pm 429.5$ & $1,803.6 \pm 406.2$ & 0.224 & \\
\hline Carbohydrate $(\%)$ & $64.9 \pm 10.1$ & $66.1 \pm 7.7$ & 0.249 & $62.9 \pm 11.2$ & $60.5 \pm 8.6$ & 0.127 & \\
\hline Protein $(\%)$ & $13.8 \pm 2.6$ & $16.0 \pm 3.1$ & $0.003^{* *}$ & $13.1 \pm 2.1$ & $14.1 \pm 2.6$ & $0.037 *$ & \\
\hline Fat $(\%)$ & $21.4 \pm 9.0$ & $17.9 \pm 7.3$ & $0.016^{*}$ & $22.1 \pm 5.4$ & $24.8 \pm 6.5$ & $0.026^{*}$ & \\
\hline Carbohydrate (g) & $307.8 \pm 98.1$ & $195.9 \pm 47.9$ & $<0.001 * * *$ & $285.8 \pm 74.2$ & $265.7 \pm 56.5$ & $0.048 *$ & \\
\hline Protein $(\mathrm{g})$ & $62.1 \pm 14.1$ & $46.5 \pm 8.6$ & $<0.001 * * *$ & $59.3 \pm 16.7$ & $61.6 \pm 18.0$ & 0.213 & \\
\hline Fat $(g)$ & $44.3 \pm 16.5$ & $24.5 \pm 10.9$ & $<0.001 * * *$ & $48.3 \pm 19.0$ & $52.9 \pm 22.4$ & 0.174 & \\
\hline Fiber $(g)$ & $8.4 \pm 8.4$ & $7.9 \pm 3.7$ & 0.265 & $11.3 \pm 21.0$ & $6.5 \pm 3.2$ & $0.013 *$ & \\
\hline Vitamin A $(\mu g)$ & $1,081.2 \pm 1129.9$ & $1,358.5 \pm 1625.2$ & 0.198 & $1,422.5 \pm 1839.4$ & $1,977.1 \pm 2037.0$ & 0.114 & \\
\hline Carotene (mg) & $893.8 \pm 724.8$ & $876.3 \pm 540.4$ & 0.465 & $900.4 \pm 703.0$ & $643.0 \pm 499.4$ & 0.063 & \\
\hline Vitamin B1 (mg) & $1.0 \pm 0.4$ & $0.7 \pm 0.4$ & $0.006^{* *}$ & $1.1 \pm 0.5$ & $1.00 \pm 0.5$ & 0.171 & \\
\hline Vitamin B2 (mg) & $1.2 \pm 0.5$ & $1.0 \pm 0.4$ & 0.055 & $1.4 \pm 0.6$ & $1.3 \pm 0.7$ & 0.062 & $T$ \\
\hline Vitamin C (mg) & $94.5 \pm 37.9$ & $127.3 \pm 62.6$ & $0.005^{* *}$ & $119.9 \pm 59.5$ & $111.7 \pm 55.7$ & 0.227 & 1 \\
\hline Sodium (mg) & $2,071.3 \pm 925.9$ & $1,804.9 \pm 596.1$ & 0.094 & $1,678.2 \pm 625.3$ & $1,992.6 \pm 1080.6$ & 0.116 & and nutrient in \\
\hline Potassium (mg) & $734.7 \pm 372.4$ & $982.6 \pm 498.5$ & $0.013^{*}$ & $745.6 \pm 367.2$ & $692.4 \pm 300.5$ & 0.259 & between the bas \\
\hline Calcium (mg) & $330.1 \pm 131.2$ & $318.5 \pm 144.9$ & 0.373 & $362.3 \pm 125.8$ & $363.7 \pm 139.0$ & 0.481 & and the program \\
\hline \multicolumn{7}{|c|}{ Notes: $* p<0.05 ; * * p<0.01 ; * * * p<0.001$} & completion \\
\hline
\end{tabular}

\begin{tabular}{llccccc}
\hline & & At baseline & At week 16 & \multicolumn{2}{c}{ Change } \\
Variables & \multicolumn{1}{c}{ Group } & $\overline{\mathrm{x}} \pm \mathrm{SD}$ & $\overline{\mathrm{x}} \pm \mathrm{SD}$ & $\begin{array}{c}\text { Paired } t \text {-test } \\
p \text {-value }\end{array}$ & $\overline{\mathrm{x}} \pm \mathrm{SD}$ & $\begin{array}{c}\text { Student's } t \text {-test } \\
p \text {-value }\end{array}$ \\
\hline Knowledge (scores) $^{\mathrm{a}}$ & Intervention & $10.1 \pm 3.7$ & $15.9 \pm 1.2$ & $<0.001^{* * *}$ & $5.8 \pm 3.5$ & $<0.001^{* * * *}$ \\
& Control & $11.2 \pm 4.3$ & $13.0 \pm 3.4$ & $0.015^{*}$ & $1.8 \pm 4.1$ & \\
Attitude (scores) & Intervention & $3.9 \pm 0.3$ & $4.1 \pm 0.2$ & $0.005^{* *}$ & $0.2 \pm 0.4$ & $0.018^{*}$ \\
& Control & $3.8 \pm 0.3$ & $3.9 \pm 0.3$ & 0.103 & $0.1 \pm 0.3$ & \\
Physical activity (METs) & Intervention & $1.7 \pm 0.2$ & $1.9 \pm 0.2$ & $0.005^{* *}$ & $0.2 \pm 0.2$ & $<0.001^{* * *}$ \\
& Control & $1.7 \pm 0.24$ & $1.7 \pm 0.3$ & 0.124 & $0.0 \pm 0.1$ &
\end{tabular}

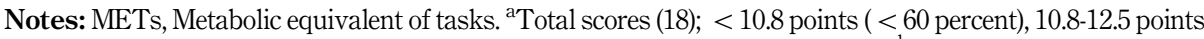
(60-69 percent), $12.6-14.3$ points (70-79 percent), $\geqslant 14.4$ points ( $\geqslant 80$ percent); ${ }^{b}$ total scores (5); 1 (strong disagreement) to 5 scores (strong agreement); ${ }^{c}$ Physical activity intensity in METs; 0-1.5 (sedentary), 1.6-2.9 (light), 3-5.9 (moderate), $\geqslant 6$ (vigorous). *p<0.05; **p $<0.01 ; * * p<0.001$

Table IV. Changes in knowledge of obesity and health, attitude toward lifestyle modification, and physical activity

\begin{tabular}{|c|c|c|c|c|c|c|}
\hline \multirow[b]{3}{*}{$\begin{array}{l}\text { Metabolic syndrome } \\
\text { component }\end{array}$} & \multicolumn{2}{|c|}{ At baseline } & \multicolumn{4}{|c|}{ At week 16} \\
\hline & $\begin{array}{l}\text { Intervention } \\
\quad(n=29)\end{array}$ & $\begin{array}{l}\text { Control } \\
(n=30)\end{array}$ & & $\begin{array}{l}\text { Intervention } \\
\quad(n=2)\end{array}$ & $\begin{array}{l}\text { Control } \\
(n=30)\end{array}$ & \\
\hline & $n(\%)$ & $n(\%)$ & $\begin{array}{l}\chi^{2} \text { test } \\
p \text {-value }\end{array}$ & $n(\%)$ & $n(\%)$ & $\begin{array}{l}\chi^{2} \text { test } \\
p \text {-value }\end{array}$ \\
\hline \multicolumn{7}{|c|}{ Number of ATP III criteria ${ }^{a}$} \\
\hline$<3$ & 18(42.1) & 17(56.7) & 0.810 & 24(82.7) & $16(53.3)$ & $0.016^{*}$ \\
\hline$\geqslant 3$ & 11(37.9) & 13(43.3) & & 5(17.3) & $14(46.7)$ & \\
\hline
\end{tabular}

Triglyceride $\geqslant 150 \mathrm{mg} / \mathrm{dl}$, High density lipoprotein cholesterol $<50 \mathrm{mg} / \mathrm{dl}$, Blood pressure $\geqslant 130 / \geqslant 85 \mathrm{mg} / \mathrm{dl}$; The metabolic syndrome diagnosis is $\geqslant 3$ of 5 criteria; ATP III National Cholesterol Education-Adult Treatment Panel III. $* p<0.05$
Table V.

Percentage of metabolic syndrome components at baseline and the 16 th week 
JHR

32,3

restricted diet (time not available), and resulted in weight loss of 6.5 percent after three months and 8.1 percent weight loss after six months[17]. The strategies used in previous studies for weight reduction have involved a range of different activities similar to this study including nutritional counseling, health education, motivational interviewing, exercise training, and behavioral modification techniques[31-33]. The effectiveness of any program involving a combination of activities, and interventionists must be to maintain the motivational level over obstacles[34]. The interventionists in many studies were generally the health profession[17, 29, 30] but had no real experience as weight loss achievers mentioned. In our study, the interventionist was not only a health professional but also a successful weight loss achiever who acted as a powerful cue to stimulate the participants to accept and conform to the program recommendations. In addition, previous diverse experience of the health professional also helped solve a problem of multidisciplinary health care team inadequacy.

The significant weight loss in our study displayed significant improvements in BMI, WC, waist-hip ratio, body fat, visceral fat, and fat-free mass. Compared with previous studies[29, 35, 36], the magnitudes of the changes observed in our study were greater because of the congruent program activities implemented by the health professional which aimed at losing weight by improving the individual's health concerns and confidence. The tailored nutritional counseling and the exercise regime allowed for the individual's unique needs to manage their health in a way that was relevant to their changing contexts, the geographical and socio-economic situations, and individual contentment. Furthermore, life safety and positive changes during weight loss were always affirmed by the health professional to support confidence.

Most participants had completed their primary education. However, they could increase their knowledge score level from 60 percent at the baseline to 80 percent at the end line and correctly estimate energy intake by following the food portion numbers. This individualized approach allowed for the needs and perceptions of the participants to be realized and stimulated, and thus strengthened their efforts to achieve the dietary and physical activity targets[37]. Using the health belief model and linkage[15] could increase individual perceptions of obesity and health and maintain confidence in eating and exercise modification. This model was effective in behavioral modification and in adherence rate (98.33 percent); the participants perceived not only their own risk and its severity, which could be life threatening, but also their ability to overcome diseases or obstacles. Health concerns have been reported to continually increase[38] as well.

The health professional was also perceived not only as a powerful cue for actions but also as a role model in weight loss. Thus, the participants endeavored to change themselves, which led to a significant decrease in energy intake and an increase in physical activity. A positive role model can inspire changes in target behaviors of individuals[39]. This has been attributed to health education, tailored nutritional counseling, and exercise training conducted by the interventionist whose skill can influence weight reduction[40]. Practical knowledge and encouragement were disseminated clearly by the health professional's directed weight loss experience. Consequently, the increased knowledge of obesity and health, attitude toward lifestyle changes, and physical activity improved significantly. These led to intended weight loss practice following the program recommendations and significant weight improvement.

An increase in intended weight loss was reported to produce more positive health impacts, and the sources of cytokine and inflammatory factors were diminished[41]. Also, a decrease in fat accumulation, particularly abdominal fat has resulted in greatly improved insulin sensitivity, dyslipidemia, and blood pressure[7, 42]. In our study, fasting blood glucose in the intervention group $(95.0 \mathrm{mg} / \mathrm{dl})$ was reduced significantly into the preferable fasting blood glucose range. This was related to improved insulin resistance, which was 
secondary to effective weight reduction[32]. Previous studies showed the greater the weight loss, the greater the improvement in insulin resistance owing to the decrease in visceral fat and $\mathrm{WC}[7,9,32,35]$.

However, the improvements in triglyceride and HDL-C levels were insignificant in this study. Similarly, previous studies showed statistical improvement of anthropometric indices, but not in HDL-C and triglyceride[17, 43]. In studies with short to intermediate periods of lifestyle modification[34, 35], a small HDL-C change was consistently seen after active calorie restriction and physical activity of moderate intensity[44]. This calorie-restricted diet led to disruption of HDL-C production in the short term, but $\mathrm{HDL}-\mathrm{C}$ levels later returned in the weight maintenance phase[44]. Therefore, a slight decline in HDL-C was not surprising[34]. In triglycerides, the high baseline levels decreased to normal levels after week 16 in the intervention group, although our research showed no statistical improvement. The lack of statistical improvement might be due to the high carbohydrate intake of the eating culture in Northeastern Thailand; this involves a high glycemic index diet including glutinous rice two to three times per day[45]. A high glycemic index diet has been reported to contribute to higher triglyceride levels[46]. In contrast, a lower glycemic index diet was significantly associated with lower triglyceride and higher HDL-C levels[47]. Additionally, low physical activity was positively associated with triglyceride because the body was unable to reduce triglyceride to normal levels[48]. In this study, although most participants performed moderate exercise at 150 minutes/week, their physical activity remained at a light or even sedentary level ( $\leqslant 3$ METs)[22], which might indicate a slow decrease in triglyceride.

Our study showed blood pressure was lowered in non-hypertensive participants to an optimal level. The non-hypertensive participants showed reductions of 7.4 and $5.2 \mathrm{mmHg}$ in systolic and diastolic blood pressures, respectively. Blood pressure improvement is reported to be sensitive to weight reduction, which was a main factor in blood pressure regulation[49]. This study was more effective than previous studies and is most likely due to the differences in the underlying theory, course content, interventionist qualification and program implementation.

Unexpectedly, with regards to the metabolic syndrome participants in the intervention group, the metabolic syndrome numbers decreased 54.6 percent after week 16 . In comparison with a previous study, the result of the lifestyle modification on cardiometabolic risks among female obese participants with metabolic syndrome showed that the metabolic syndrome number decreased by 45.2 percent after 24 weeks[17]. Remarkably, our study revealed that the obese women in the intervention group had a 76 percent lower chance of developing metabolic syndrome. These showed that the program greatly effected metabolic syndrome sufferers. Furthermore, most participants in the intervention group who could be followed-up after eight months generally seemed to maintain weight loss of over 7 percent (data not shown), although this was gradually regained. Participants who had achieved over 10 percent of weight loss showed excellent weight maintenance. At present, the challenge for public health professionals is to develop serious and sustainable obesity management methods.

The major limitations of this study include the geographical limitation of the rural areas in Khon Kaen Province. The results may not be able to be generalized to other areas. The MET calculation from physical activity did not use high technology devices and may not have been accurate, although the results indicated changes in the physical activity level. The health profession and professional staff who ran the program could not be blinded to the intervention. The larger scale for the program implementation was unable to expand due to budget and expertise limitation. Therefore, the results should be interpreted carefully.

Since there is still no evidence providing that "efficacy study" of this program is applicable on larger scale and in the "real world" practice, it may be too early or premature to provide any policy recommendation concerning this program. 
JHR

32,3

214

\section{References}

1. The GBD 2013 Obesity Collaboration, Ng M, Fleming T, Robinson M, Thomson B, Graetz B, et al. Global, regional and national prevalence of overweight and obesity in children and adults 1980-2013: a systematic analysis. Lancet. 2014; 384(9945): 766-81.

2. Aekplakorn W, Mo-Suwan L. Prevalence of obesity in Thailand. Obes Rev. 2009; 10(6): 589-92.

3. Aekplakorn W. National Health Examination Survey IV report. Nonthaburi: Graphigo System; 2012.

4. Aekplakorn W, Hogan MC, Chongsuvivatwong V, Tatsanavirat P, Chariyalertsak S, Boonthum AS, et al. Trends in obesity and associations with education and urban or rural residence in Thailand. Obesity. 2007; 15(12): 3113-21.

5. Aekplakorn W, Kessomboon P, Sangthong R, Chariyalertsak S, Putwatana P, Inthawong R, et al. Urban and rural variation in clustering of metabolic syndrome components in the Thai population: results from the fourth National Health Examination Survey 2009. BMC Public Health. 2011 Nov 10; 11: 1-9, doi: 10.1186/1471-2458-11-854

6. Fulop T, Tessier D, Carpentier A. The metabolic syndrome. Pathol Biol. 2006; 54(7): 375-86.

7. Mottillo S, Filion KB, Genest J, Joseph L, Pilote L, Poirier P, et al. The metabolic syndrome and cardiovascular risk: a systemic review and meta-analysis. J Am Coll Cardiol. 2010; 56(14): 1113-32.

8. Steinbaum SR. The metabolic syndrome: an emerging health epidemic in women. Prog Cardiovasc Dis. 2004 Jan-Feb; 46(4): 321-36.

9. Ritchie SA, Connell JM. The link between abdominal obesity, metabolic syndrome and cardiovascular disease. Nutr Metab Cardiovasc Dis. 2007 May; 17(4): 319-26.

10. Wadden TA, Butryn ML, Wilson C. Lifestyle modification for the management of obesity. Gastroenterology. 2007; 132(6): 2226-38.

11. Wing RR, Lang W, Wadden TA, Safford M, Knowler WC, Bertoni AG, et al. Benefits of modest weight loss in improving cardiovascular risk factors in overweight and obese individuals with type 2 diabetes. Diabetes Care. 2011 Jul; 34(7): 1481-86, doi: 10.2337/dc10-2415

12. Liou D, Bauer KD. Exploratory investigation of obesity risk and prevention in Chinese Americans. J Nutr Educ Behav. 2007 May-Jun; 39(3): 134-41.

13. Champion VL, Skinner CS. The health belief model. In: Glanz K, Rimer BK, Viswanath K, editors. Health behavior and health education: theory, research, and practice. 4th ed., San Francisco, CA: Jossey-Bass; 2008. 45-65.

14. Diaz RG, Esparza-Romero J, Moya-Camerena SY, Roble-Sardin AE, Valencia ME. Lifestyle intervention in primary care settings improves obesity parameters among Mexican youth. J Am Diet Assoc. 2010 Feb; 110(2): 285-90, doi: 10.1016/j.jada.2009.10.042

15. Miltenberger RG. Behavior modification principle and procedures. 4th ed., Belmont, CA: Thomson Wadsworth; 2008.

16. Bernard R. Fundamentals of biostatistics. 5th ed., Duxbery: Thomson Learning; 2000. 308.

17. Oh EG, Bang SY, Hyun SS, Kim SH, Chu SH, Jeon JY, et al. Effects of a 6-month lifestyle modification intervention on the cardio metabolic risk factors and health-related qualities of life in women with metabolic syndrome. Metabolism. 2010 Jul; 59(7): 1035-43, doi: 10.1016/ j.metabol.2009.10.027

18. Miller WR, Rose GS. Toward a theory of motivational interviewing. Am Psychol. 2009; 64(6): 527-37.

19. Emmons KM, Rollnick S. Motivational interviewing in health care settings opportunities and limitations. Am J Prev Med. 2001 Jan; 20(1): 68-74.

20. Diabetes Prevention Program Research Group. The diabetes prevention program (DPP): description (DPP) of lifestyle intervention. Diabetes Care. 2002 Dec; 25(12): 2165-71.

21. Holli BB, Maillet JOS, Beto JA, Calabrese RJ. Communication and education skills for dietetics professionals. 5th ed., Baltimore: Lippincott Williams and Wilkins; 2009. 
22. Strath SJ, Kaminsky LA, Ainsworth BE, Ekelund U, Freedson PS, Gary RA. Guide to the assessment of physical activity: clinical and research applications: a scientific statement from the American Heart Association. Circulation. 2013 Nov 12; 128(20): 2259-79, doi: 10.1161/01. cir.0000435708.67487.da

23. Nutrition Division, Department of Health, Ministry of Public Health. Nutritive values of Thai foods. Bangkok: The War Veterans Organization of Thailand Publishing; 2001.

24. Sadler DR. Interpretations of criteria-based assessment and grading in higher education. Assess Eval Higher Educ. 2005; 30(2): 175-94.

25. Srisatidnarakul B. Development and validation of research instrument: psychometric properties. Bangkok: Chulalongkorn University Printing House; 2013.

26. Ainsworth BE, Haskell WL, Whitt MC, Irwin ML, Swartz AM, Strath SJ, et al. Compendium of physical activities: an update of activity codes and MET intensities. Med Sci Sports Exerc. 2000 Sep; 32(S9): S498-504.

27. Nutrition Division, Department of Health, Ministry of Public Health. Dietary reference intake for Thais. Bangkok: The Express Transportation Organization of Thailand Publishing; 2003.

28. Alberti KGMM, Eckel RH, Grundy SM, Zimmet PZ, Cleeman JI, Donato KA, et al. Harmonizing the metabolic syndrome: a joint interim statement of the International Diabetes Federation task force on epidemiology and prevention; National Heart, Lung and Blood Institute; American Heart Association; World Heart Federation; International Atherosclerosis Society; International Association for the Study of Obesity. Circulation. 2009 Oct 20; 120(16): 1640-45, doi: 10.1161/ CIRCULATIONAHA.109.192644

29. Pettman TL, Buckley JD, Misan GMH, Coates AM, Howe PRC. Health benefits of a 4-month groupbased diet and lifestyle modification program for individuals with metabolic syndrome. Obes Res Clin Pract. 2009 Nov; 3(4): 221-35, doi: 10.1016/j.orcp.2009.06.002

30. Tsai AG, Felton S. Six month outcomes of a primary care-based weight loss trial using a lay-trained counselor. J Obes Weight Loss Ther. 2014 Feb 1; 4(1): 1-15, doi: 10.4172/2165-7904.1000209

31. Hartmann-Boyce J, Johns DJ, Jebb A, Aveyard P. Effect of behavioural techniques and delivery mode on effectiveness of weight management: systematic review, meta-analysis and meta-regression. Obes Rev. 2014 Jul; 15(7): 598-609, doi: 10.1111/obr.12165

32. Levy RL, Finch EA, Crowell MD, Talley NJ, Jeffery RW. Behavioral intervention for the treatment of the obesity: strategies and effectiveness data. Am J Gastroenterol. 2007; 102(10): Oct, 2314-21.

33. Franz MJ, Boucher JL, Rutten-Ramos S, VanWormer JJ. Lifestyle weight-loss intervention outcomes in overweight and obese adults with type 2 diabetes: a systematic review and meta-analysis of randomized clinical trials. J Acad Nutr Diet. 2015 Sep; 115(9): 1447-63, doi: 10.1016/ j.jand.2015.02.031

34. Yamaoda K, Tango T. Effects of lifestyle modification on metabolic syndrome: a systematic review and meta-analysis. BMC Med. 2012 Nov 14; 10: 1-10, doi: 10.1186/1741-7015-10-138

35. Lee HO, Yim JE, Kim YS, Choue R. Moderate diet-induced weight loss is associated with improved insulin sensitivity in the middle age healthy obese Korean women. Nutr Res Pract. 2014 Aug; 8(4): 469-75, doi: 10.4162/nrp.2014.8.4.469

36. Orchard TJ1, Temprosa M, Goldberg R, Haffner S, Ratner R, Marcovina S, et al. The effect of metformin and intensive lifestyle intervention on the metabolic syndrome: the Diabetes Prevention Program randomized trial. Ann Intern Med. 2005 Apr 19; 142(8): 611-9.

37. Kreuter MW, Bull FC, Clark EM, Oswald DL. Understanding how people process health information: a comparison of tailored and untailored weight loss materials. Health Psychol. 1999 Sep; 18(5): 487-94.

38. Hamuleh M, Vahed S. Effects of education based on health belief model on dietary adherence in diabetic patients. J Diabetes Metab Disord. 2010; 9: 1-6.

39. Lockwood P, Jordan, Christain $\mathrm{CH}$. Motivation by positive or negative role models: regulatory focus determines who will best inspire us. J Pers Soc Psychol. 2002 Oct; 83(4): 854-64. 
40. Lok KYW, Chan RSM, Sea MMM, Woo J. Nutritionist's variation in counseling style and the effect on weight change of patients attending a community based lifestyle modification program. Int J Environ Res Public Health. 2010 Feb; 7(2): 413-26, doi: 10.3390/ijerph7020413

41. Chae JS, Paik JK, Kang R, Kim M, Choi Y, Lee SH. Mild weight loss reduces inflammatory cytokines, leukocyte count, and oxidative stress in overweight and moderately obese participants treated for 3 years with dietary modification. Nutr Res. 2013 Mar; 33(3): 195-203, doi: 10.1016/j.nutres.2013.01.005

42. Bays HE, Toth PP, Kris-Etherton P, Abate N, Aronne LJ, Brown WV, et al. Obesity, adiposity, and dyslipidemia: a consensus statement from the National Lipid Association. J Clin Lipidol. 2013 Jul-Aug; 7(4): 304-83, doi: 10.1016/j.jacl.2013.04.001

43. Shin MJ, Kim OY, Koh SJ, Chae JS, Kim JY, Jang Y, et al. Modest weight loss does not increase plasma adiponectin levels: effects of weight loss on C-reactive protein and DNA damage. Nutr Res. 2006; 26(8): 391-6.

44. Dobiasova M, Frohlich J. Understanding the mechanism of LCAT reaction may help to explain the high predictive value of LDL/HDL cholesterol ratio. Physiol Res. 1998; 47(6): 387-97.

45. Ranawana DV, Henry CJ, Lightowler HJ, Wang D. Glycaemic index of some commercially available rice and rice products in Great Britain. Int J Food Sci Nutr. 2009; 60(S4): 99-110, doi: 10.1080/ 09637480802516191

46. Parks EJ. Effect of dietary carbohydrate on triglyceride metabolism in human. J Nurt. 2001; 131(10): s2772-4.

47. Pelkman CL. Effects of the glycemic index of foods on serum concentrations of high-density lipoprotein cholesterol and triglycerides. Curr Atheroscler Rep. 2001 Nov; 3(6): 456-61.

48. Lyu S, Su J, Xiang Q, Wu M. Association of dietary pattern and physical activity level with triglyceride to high-density lipoprotein cholesterol ratio among adults in Jiangsu, China: a cross-sectional study with sex-specific differences. Nutr Res. 2014 Aug; 34(8): 674-81, doi: 10.1016/ j.nutres.2014.07.007

49. Annesi JJ. Comparative effects of improved cardiorespiratory fitness, stress and weight on blood pressure in a community-based treatment: implications for physician referral. The Open Public Health J. 2012; 5: 10-4.

\section{Corresponding author}

Karunee Kwanbunjan can be contacted at: karunee.kwa@mahidol.ac.th

For instructions on how to order reprints of this article, please visit our website: 